\title{
Code Hero - Catherine Barkley in A Farewell to Arms
}

\author{
Nengwei Fan \\ School of Foreign Languages, Yancheng Teachers University, Yancheng \\ Correspondence: Yancheng Teachers University, Yancheng City, Jiangsu Province, China. E-mail: \\ classforyc@163.com
}

Received: November 1, 2018

Accepted: December 10, 2018 Online Published: December 18, 2018

doi:10.5430/wjel.v9n1p29

URL: https://doi.org/10.5430/wjel.v9n1p29

\begin{abstract}
A Farewell to Arms is Hemingway's early masterwork which is known as a literary classic of modern literature. Catherine Barkley is the heroine in the novel which has aroused heated discussions. The paper tries to analyze Catherine Barkley from perspective of Code Hero as put forward by Philip Young. Catherine's personality as code hero is analyzed in detail in the paper. Her personality is discussed from three aspects: concept of life, reaction to pressure and mental outlook.
\end{abstract}

Keywords: A Farewell to Arms, Catherine Barkley, Code Hero

\section{Introduction}

Ernest Hemingway is one of the most influential writers in the world. A Farewell to Arms is an earlier Hemingway's masterwork, which is known as a literary classic of modern literature. The novel is created in accordance with Hemingway's personal experience in World War I. It narrates a pathetic and touching elegy of love during the era of war.

Hemingway has created a series of tough guy images in his works. Adventurous activities such as fishing, hunting, boxing, bull fighting and wars are considered as prominent themes of his works. Therefore, conventional criticism about Hemingway from male-dominant circle often centers about his typical masculinity, his male heroes-dauntless, unyielding. In their eyes, Hemingway's literary world is dominated by man, and women are put on the margins. Some depict Hemingway's woman as mindless, soft, subservient-animal or thing. Some even believe that Hemingway keeps a growing antagonism to women. In fact, Hemingway has devoted himself to depicting many kinds of female figures that are principled and courageous, among whom Catherine Barkley in A Farewell to Arms is typical. Looking into Hemingway's works, it is possible to comprehend Hemingway's deep understanding of females.

Catherine Barkley, the heroine in A Farewell to Arms, is a female figure who has aroused heated discussion. Unfortunately, Catherine has repeatedly misunderstood by the critics. Millicent Bell calls Catherine a sort of inflated rubber woman available at will to the onanistic dreamer (Bell, 1984). Mimi Reisel Gladstein furthers the anti-Catherine argument by insisting that Catherine is definitely other, object not subject. She is reduced to playing the role of functionary in man's fulfillment (Gladstein. 1986). Biographer Kenneth Lynn acknowledges Catherine's beauty, yet he also mentions that she possesses a jittery, neurotic manner (Lynn, 1987). Robert Lewis, who credits Catherine for her insight and heroic nature, nevertheless feels that she is, in a way, a one-dimensional pasteboard figure (Lewis, 1992). Jeffrey Meyers claims that Catherine is purely a sexual object (Meyers, 1985). Edmund Wilson asserts that She is not convincing as a human personality (Wilson, 1985). H.L.Mencken says similarly that she scarcely seems human at all (Mencken, 1996).

In fact, Catherine is such a woman that she treats love as everything and regards love as the center of her life. She is a selfless individual who recognizes that that others-like Frederic Henry-need more of her than she needs of herself. As a single woman, Catherine ignores her female dignity to cater to Henry. As a nurse, Catherine nearly works all the night shifts in the hospital to stay with Henry during his treatment, regardless of the true mission of her work and her own health.

Philip Young is the first scholar who puts forward Hemingway Code Hero. According to Young, such a character is a man who is usually but not always associated with Hemingway himself in some way; who is skilled; who does not think or talk about "it" regardless of what "it" might be; and who takes great pleasure in life, in the 
forms of food, alcohol, and sex. For Young, he who possesses the code knows-the controls of honor and courage which in a life of tension and pain make a man a man and distinguish him from the people who follow random impulses, let down their hair, and are generally messy, perhaps cowardly, and without inviolable rules for how to live holding tight (Young, 1952). Certainly, with her experience and maturity, Catherine is closer to being the "code hero" than Frederic. He may be the apprentice, learning to deal with "it", but he has not yet graduated to this stage of gallantry. If anyone understands the code in A Farewell to Arms, it is Catherine Barkley.

\section{Catherine Barkley: A Code Hero}

\subsection{Catherine's Concept of Life: Love}

During World War I, no one could predict what would happen to them in next minute. People's lives became less enjoyable and more miserable because of the war. However, Catherine considers love as her concept of life, and she yearns for love all the time. It is her concept of life that makes her life remain rich and substantial, instead of being dominated by the war. In spite of the shock of the untimely death of her fiancé, Catherine becomes more courageous and determined, and she gets a clear idea of what she really wants. Catherine hopes that her life is filled with the warmth of love, and she dares to give up everything she has to pursue love.

Catherine regards love as the most important issue in her life. When she meets Henry and falls in love with him, she tells Henry I have plenty of faults, but I am faithful. You will be sick of me, I will be so faithful, (Hemingway, 1992: 50) (Hemingway, 1992) from which people can see that at the beginning Catherine has been ready to devote herself to Henry. In order to have more time to stay together with Henry, this thin and weak woman nearly works all the night shifts during Henry's treatment in the hospital, without taking her own health into consideration. Catherine promises I will go any place and any time you wish,(Hemingway, 1992: 180) (Hemingway, 1992) when she learns Henry is facing the danger of being arrested. Later she flees with Henry in a small boat in a stormy night, even though she doesn't know the future before her.

Catherine is such a woman who puts love in the first place that she even doesn't care about a legal marriage. When it comes to marriage, Henry wants Catherine to get married with him, but Catherine refuses. The reasons are that if they get married, Catherine would be sent away. If they merely start on the formalities, officials would watch Catherine and break them up. What's more, they have to get married in accordance with Italian law. Catherine refuses because she has a quite clear understanding that all those annoying issues will prevent them from staying together and owning a happy life. What Catherine replies to Henry is significantly impressive: There isn't any me. I'm you. Don't make up a separate me. We are married privately. You see, darling, it would mean everything to me if I had any religion. But I haven't any religion, you are my religion. You are all I've got. (Hemingway, 1992: 84-85) (Hemingway, 1992) At the first glance, Catherine's attitude towards this issue is dubious: why does a good girl care little about her valuable reputation? How can an ordinary girl say "No" to marriage? In fact, due to the death of her previous fiancé, Catherine has realized that getting or not is just an external form and has no essential importance. Catherine knows clearly that everything in this world is tiny and fragile, and all the issues that people cherish can be destroyed in no time, including marriage. Thus, when Catherine meets and falls in love with Henry, she is willing to sacrifice every inch of herself, regardless of the promise of a legal marriage.

Another important point is Catherine's attitudes towards Henry's leave, which shows her permanent pursuit of love. It is cruel and unacceptable for a couple in love to separate from each other, let alone in the time of war when everything cannot be predicted. When Henry receives his papers and the leave, Catherine, the ordinary woman, behaves herself with great composure in face of the separation and she still keeps a positive outlook on her future with Henry. When she dates a soldier, Catherine has already prepared for the inevitable separation, and she has made up her mind to stick to their love at the very beginning, no matter what happens. Therefore, Catherine promises to Henry that she is willing to sacrifice anything and company him to go wherever he wants to go.

Catherine's actions are based upon love-her concept of life. And this concept of life endows her with a strong will when she is faced with all difficulties in life, and helps her to become a Code Hero.

\subsection{Catherine's Reaction to Pressure: Graceful}

Life is definitely filled with all kinds of hardship, especially during the years of war, and no one can be expected. Catherine is an ordinary nurse who works for the army, but what makes her special is her grace under pressure in a life of tension and pain. Catherine has real inner strength, which enables her to look at the positive side and show her grace all the time.

Catherine shows her grace under pressure in her life incessantly. When Henry has to leave for the front, she doesn't 
feel sad to the cruel truth at all. Instead, she looks forward to their next reunion. At the moment when she is going to have birth to her child, Catherine doesn't feel any panic or anxious, and what she can only feel is excitement and expectation for her lovely baby. Even on her deathbed, Catherine still holds her grace, and faces the last ending peacefully.

Besides, Catherine's response to the unplanned pregnancy is a good illustration of her grace under pressure. In spite of all means of contraception, Catherine still gets pregnant by chance and has to bear the burden. When she knows that she is going to have an unexpected baby, she accepts the fact tranquilly without any doubt or complaint. What's more, Catherine even decides to keep it secret from Henry and to take on the responsibility alone. Catherine is such a selfless and thoughtful woman that she is afraid that the news will make Henry unhappy or worried. As a result, she would rather hide the truth and bear the huge pressure on her own. For an unmarried woman who has a baby accidentally, what she has to face is endless condemn and great disaster in that conservative era, which is definitely oppressive and unimaginable. Nevertheless, when it happens to Catherine, her reaction is much too calm and fearless, as though all the scandals and all the obstacles are just little things in her life, which don't deserve any extra attention. People have babies all the time. Everybody has babies. It's a natural thing. I will look after all that, (Hemingway, 1992: 101-102) (Hemingway, 1992) Catherine says so. Catherine is so brave and optimistic that nothing can truly defeat her desire for life. In her mind, although humans are insignificant and maybe unable to control their own fates, they should not be pessimistic or desperate. What people really should do is to confront the fact positively and actively, and try to solve those problems by all means. Catherine thinks in that way, and she also behaves in that way. Consequently, when Henry gets back to the front, this brave lady endures the sensation of physical pain and inconvenience of life which are caused by the baby on her own. She waits for the day when Henry comes back devoutly. It turns out that Catherine is absolutely worthy of the phase Code Hero, who shows grace under pressure during her lifetime.

In addition, Henry and Catherine's escape to Switzerland also shows her grace under pressure vividly. As the barman informs Henry of his arrest in the early morning, they have to flee the country at very night, and their journey of escape begins. The storm is over, but it is rough. It is 11 p.m. at night, and they have to row in the lake nearly 8 hours to reach their destination, if they are lucky. In spite of the dark night, the cold wind, the giant lake, and all the unknown things, Catherine still tries to keep optimistic. She also seeks and enjoys the pleasure during the unique trip with Henry. For her, she is fearless of all kinds of hardship, and she is ready to cherish all the issues she has experienced in her life, whether they are good or not. On their way, an idea occurs to Catherine that they can sail with the umbrella with the wind to row more smoothly. At first, the idea works. The boat is moving faster and they are going beautifully, until all of a sudden the umbrella buckles and goes inside out. At the sight of this scene, instead of disappointment, Catherine bursts into laughter and keeps on laughing. Compared with Catherine's grace under pressure, Henry is rather frustrated as the accident makes it harder to get into the border of Swiss before dawn. Catherine explains to Henry that the scene is quite funny: he looks about twenty feet broad and he is very affectionate holding the umbrella by the edges. After that, Catherine even comments that it is a grand night, completely ignoring the truth that they are actually escaping and risking their lives. Fleeing in the lake in the middle of the night is absolutely not an enviable experience, but Catherine is extraordinary relaxed, and she seems to leave all the sufferings behind, just trying to enjoy the different experiences throughout her lifetime. Catherine holds such an optimistic attitude towards life that she is always able to show her grace under pressure.

In this novel, people can see that Catherine always keeps a positive and active attitude toward difficulties, and her grace under pressure in face of bad sufferings is quite impressive.

\subsection{Catherine's Mental Outlook: toughness}

On her way to pursuing love, Catherine has already experienced a number of challenges, but never has she given up. Catherine has a kind of indestructible spirit, which helps her get over all those miseries happening to her.

Catherine's fiancé dies in the war unfortunately, which has shocked her a lot. Though it is difficult to accept, Catherine gets over the tremendous grief, and becomes much more courageous and determined later. At the same time, she gets to know clearly the essence of the war. When Catherine falls in love with Henry, she faces the fact of accidental pregnancy bravely, although it is a great risk for an unmarried woman. When she gives birth to her child, she fights with death firmly until the last minute. And even when she bleeds to death at last, Catherine doesn't feel afraid of death, and doesn't submit to it. Instead, she faces her death with courage and peace.

Catherine's fight against pains when she gives birth to her baby is a good illustration of her indestructible spirit. At that night, Catherine is about to give birth to her child. When she begins to have pains almost regularly, unlike most of mothers, she doesn't feel vulnerable or frightened of the following pains. On the contrary, Catherine becomes very 
excited and expectant. She says to Henry I'm so glad that it has started, and she thinks that "now in a little while it will be all over.(Hemingway, 1992: 210) (Hemingway, 1992) Catherine is such a brave and fearless woman that when the pain begins to emerge, she is fearless and just looking forward to the end of her gestation. Her source of happiness and courage originates from the birth of her lovely child, while the pains in the process are just insignificant and mean nothing to her.

Afterwards, when Catherine is well placed in the ward, much more unbearable pains begin to torture her quite often. The pains come quite regularly followed by slackening, while Catherine looks much more excited than before. "When the pains were bad she called them good ones; when they started to fall off she was disappointed and ashamed" (Hemingway, 1992: 214). As we are all known, the pains women have to bear when they give birth to a child are unimaginably tremendous. Some women can't bear the huge pain and shout at the top of their voice, some are in a confused state of mind tortured by the pain, and some others even want to give up at the very beginning. However, Catherine is absolutely unique and extraordinarily brave: she expects the horrible pain and demonstrates resilience when she is faced with much stronger pain. When she persuades Henry to go out and have a meal, the strong-minded woman says: I so want to be a good wife and have this child without any foolishness. (Hemingway, 1992: 224) (Hemingway, 1992) Catherine's indestructible spirit enables her to overcome the fear about immense pains in the process, and makes her much more determined. Catherine is out of question a true Code Hero. She struggles against unbearable pains firmly, and she even looks forward to those pains and praises them.

Catherine is like a brave warrior who is prepared to welcome any enemies and is ready to beat them with her strong will and determination. Catherine cannot be defeated, because she is a woman with indestructible spirit.

\section{Conclusion}

Above all, Catherine Barkley in A Farewell to Arms is not a mere appendix to men, but an extremely important figure in the novel. Catherine has a thorough understanding of life, and she spends all her life yearning for true love, which makes her life much richer and more substantial. Catherine also plays a significant role in Henry's life. Catherine's eager faith in life and indifference to death also encourages Henry to be a brave man. Henry doesn't have much practice in love and life: it is Catherine who shares her comprehension with him, and leads to his final maturity. At the end of the novel, when Catherine bleeds to death in the ward, and their little child is also dead, Henry is finally awakened to the truth that he cannot rely on anyone or anything. He realizes that what he really should do is to face life bravely, and get over those difficulties and obstacles on his own. Thanks to Catherine, Henry is becoming a brave man and begins to get a clear understanding of life.

Catherine is a responsible nurse, a considerate "wife", and a determined and optimistic warrior. Catherine regards love as her concept of life, and she yearns for love all the time. Catherine is clearly aware of what she really cherishes, and she has a strong will to achieve it at all costs. It is her concept of life that makes her life much more substantial, instead of being over-influenced by the war. What's more, Catherine is able to show her grace in face of all the unfortunate sufferings. People can see that Catherine always keeps positive and active attitudes towards difficulties and obstacles, and her grace under pressure in face of bad sufferings is quite impressive. Besides, Catherine has an indestructible mental outlook. The strong will and determination help Catherine to get over a lot of obstacles in her life. Thus, Catherine embodies Philip Young's idea about Code Hero: the one shows honor, courage, and endurance in a life of tension and pain. The firmness and resolution of Catherine makes her much closer to a Code Hero, rather than Henry.

Above all, Hemingway can not only tough guys who are in face of death, but can also describe female images who are able to confront disasters with calm. As Hemingway says before, which is regarded as the most obvious trademark of Code Hero, the world crushes every person into pieces, yet a lot of people arise from the pieces to demonstrate their staying power. Such examples can be seen in A Farewell to Arms Catherine Barkley is definitely a Code Hero.

\section{References}

Bell, Millicent. (1984). A Farewell to Arms: Pseudo-autobiography and Personal Metaphor. In Ernest Hemingway, The Writer in Context, ed. Nagel, James, 107-28. Madison: University of Wisconsin Press.

Gladstein, M. R. (1986). The Indestructible Woman in Faulkner, Hemingway, and Steinbeck. Ann Arbor: UMI Research Press.

Hemingway, E. (1992). A Farewell to Arms. Beijing: Foreign Language Teaching and Research Press.

Lewis, R. W. (1992). A Farewell to Arms: The War of the Words. New York: Twayne Publishers. 
Lynn, K. (1987). Hemingway. New York: Simon and Schuster.

Mencken, H. L. (1996). The Burden of Credulity. Oxford University Press.

Meyers, J. H. (1985). A Biography. New York; Haroer and Row.

Wilson, E. (1985). Hemingway: Gauge of Morale. Ernest Hemingway. Ed .Harold Bloom.Chelsea House Publishers.

Young, P. (1952). Ernest Hemingway. New York: Rinehart. 